Volume 13

Issue 2 Rethinking Genocide, Mass Atrocities,

and Political Violence in Africa: New Directions,

Article 5

New Inquiries, and Global Perspectives

6-2019

\title{
Transnational Advocacy: Genocide or Terrorism?
}

Terrence Lyons

George Mason University

Follow this and additional works at: https://digitalcommons.usf.edu/gsp

\section{Recommended Citation}

Lyons, Terrence (2019) "Transnational Advocacy: Genocide or Terrorism?," Genocide Studies and Prevention: An International Journal: Vol. 13: Iss. 2: 14-21.

DOI:

https://doi.org/10.5038/1911-9933.13.2.1702

Available at: https://digitalcommons.usf.edu/gsp/vol13/iss2/5

This is brought to you for free and open access by the Open Access Journals at Digital Commons @ University of South Florida. It has been accepted for inclusion in Genocide Studies and Prevention: An International Journal by an authorized editor of Digital Commons @ University of South Florida. For more information, please contact digitalcommons@usf.edu. 


\title{
Transnational Advocacy: Genocide or Terrorism?
}

\author{
Terrence Lyons \\ George Mason University \\ Fairfax, Virginia, USA
}

In recent decades globalization has made transnational networks critical to understanding conflict dynamics and how diaspora political activities shape policy outcomes. Why did Tibet become an international controversy while the similar struggle by the Uyghurs received far less attention from the media and transnational advocacy networks? ${ }^{1}$ How have transnational advocacy networks led to the diffusion of global norms on human rights? ${ }^{2}$ On many issues, such as LGBT rights, competing networks of activists mobilize and contend with each other to shape global narratives and specific policy outcomes. ${ }^{3}$ Transnational networks and diaspora also contribute to what some reference as the "dark side" of globalization and serve to support hyper-nationalist movements, international criminal syndicates, and arms trafficking. ${ }^{4}$

International policy toward genocide is shaped in part by how transnational advocacy groups frame the message and how competing networks push alternative approaches. Scholars have pointed out the ways that transnational networks play key roles in how issues are framed. Bob has emphasized the roles of gatekeepers in the construction of issues for advocacy networks. ${ }^{5}$ The process through which Darfur was labelled as genocide was deeply contentious and raised deep issues about how the world should position itself with regard to violence, particularly in Africa and the Islamic world. ${ }^{6}$ As Irvin-Erickson argued, "genocide discourses" are a type of strategic narrative that shapes the way that individuals and groups position themselves. ${ }^{7}$

In many cases one set of actors seeks to portray a conflict as genocide while another seek to label one or another parties to the conflict as terrorist. The genocide and terrorism frameworks both work to make conflict fundamentally apolitical and to make one set of actors innocent victims and the other perpetrators. Alex Bellamy has argued in the context of the Responsibility to Protect (R2P) doctrine "counter-terrorism and R2P are simply different ways of talking about the same problem: violent attacks on civilian populations." ${ }^{8}$ While The Convention on the Prevention and Punishment of the Crime of Genocide has specific legal language on the components of genocide, in the political realm the label is used in response to transnational advocacy and mobilization.

This article will examine the efforts by the Ethiopian government and its allies on one side and the Ogaden National Liberation Front and its supporters in the diaspora on the other to shape whether the violence in the Somali region of eastern Ethiopia should be regarded as "genocide" or "terrorism." In other words, the determination of what kind of conflict was taking place in the Somali region of Ethiopia was shaped by transnational political processes. Conflict between highland Ethiopians and the Somali-speaking people of eastern Somalia (often called the Ogaden, after the largest Somali clan that lives there) has a long history. A low level insurgent war between the Ogaden National Liberation Front (ONLF) and the Ethiopian government escalated sharply

\footnotetext{
${ }^{1}$ Clifford Bob, The Marketing of Rebellion: Insurgents, Media, and International Activism (New York: Cambridge University Press, 2005).

${ }^{2}$ Margaret E. Keck and Kathryn Sikkink, Activists Beyond Borders: Advocacy Networks in International Politics (Ithaca: Cornell University Press, 1998).

${ }^{3}$ Clifford Bob, The Global Right Wing and the Clash of World Politics (New York: Cambridge University Press, 2012).

${ }^{4}$ Jorge Heine and Ramesh Thakur, eds., The Dark Side of Globalization (New York: United Nations University Press, 2011).

${ }^{5}$ Bob, Marketing of Rebellion. While Bob emphasizes NGO networks, the argument here extends the same logic to diaspora networks. See also, R. Charli Carpenter, "Setting the Advocacy Agenda: Theorizing Issue Emergence and Nonemergence in Transnational Advocacy Networks," International Studies Quarterly 51, no. 1 (2007), 99-120. DOI: 10.1111/j.1468-2478.2007.00441.x

${ }^{6}$ Mahmood Mamdani, “The Politics of Naming: Genocide, Civil War, Insurgency," London Review of Books 29, no. 5 (March 8, 2007), 5-8.

${ }^{7}$ Douglas Irvin-Erickson, "Genocide Discourses: American and Russian Strategic Narratives of Conflict in Iraq and Ukraine," Politics and Governance 5, no. 3 (2017), 130-145. DOI:10.17645/pag.v5i3.1015

${ }^{8}$ Alex Bellamy, "The Islamic State and the Case for Responsibility to Protect," OpenCanada.org, April 20, 2015, accessed June 1, 2018, https://www.opencanada.org/features/the-islamic-state-and-the-case-for-responsibility-to-protect/.
} 
in 2007 following a rebel attack on a Chinese facility exploring for natural gas. ${ }^{9}$ The ONLF and its supporters in the diaspora community demanded that the international community recognize this violence as a genocide and respond appropriately. At the same time, the regime in Addis Ababa and its allies insisted that the ONLF was a terrorist organization working in collusion with Ethiopia's regional rival Eritrea and al-Shabaab Islamists in Somalia and therefore should be designated as a foreign terrorist organization, which would cut off funding sources in the diaspora. This transnational advocacy contest took place in Europe, North America, and involved governments and diaspora populations making claims on behalf of populations to which they were linked through global networks.

\section{The Ethiopian Diaspora}

In Ethiopia, as in many parts of the world, political dynamics have been transformed by globalization and the development of innovative transnational social networks. These new political processes are rooted in communities that are increasingly less restricted by geographic location or by the notion that actors outside a state are not members of communities rooted within a specific jurisdiction. These new transnational politics of diaspora networks are often intensely focused on specific locations, identities, and processes of contention. ${ }^{10}$ In the Ethiopian case, as in other cases of "conflict-generated" diasporas such as the Tamil, Armenian, or Irish, diaspora communities have a tendency to frame homeland struggles in categorical, hard-line terms that strengthen locally based confrontational leaders and movements.

The Ethiopian diaspora in North America has its origins in Ethiopia's violent political transitions and protracted conflicts. Many key leaders in the diaspora had engaged in the radical student politics of the early 1970s and have remained active in Ethiopia's politics from abroad ever since. The diaspora played a crucial role in the political opening of 2005 and the subsequent crisis and crackdown. The EPRDF regime vigorously criticized what it labeled as "extremists" in the diaspora and insisted that the diaspora had no legitimate role in Ethiopia's domestic politics. In Ethiopia, as in many parts of the world, local politics are transnational, as power, constituencies, and ideas in diaspora communities influence political outcomes at home.

\section{Transnational Politics and the Ogaden National Liberation Front}

The importance of transnational processes involving diaspora politicians will be illustrated in this article through the case of advocacy around the war between the Ethiopian regime, led by the ruling Ethiopian People's Revolutionary Democratic Front (EPRDF), and the Ogaden National Liberation Front (ONLF) in the late 2000s. The two opposing sides sought to embed their advocacy within powerful global narratives. The EPRDF used the language of the global war on terrorism and sought to have the ONLF classified and treated internationally in the same way as al-Qaeda, the Islamic State, or al-Shabab. The ONLF and its allies in the diaspora, however, activated the powerful frames around genocide and sought to have the war in the Ogaden understood in the same way as Darfur or Rwanda. One facet of the war in the Ogaden, therefore, was a transnational battle to shape international understanding and therefore policies of the conflict as either terrorism or genocide.

The ONLF initially participated in the Transitional Government of Ethiopia established by the EPRDF after it assumed power in 1991 and the ONLF won the 1992 local elections. After demanding self-determination, however, the party was deposed and replaced by a non-Ogadeni alliance of clans. The ONLF then engaged in a relatively low-level armed conflict, but the war escalated dramatically in 2007. In April, an ONLF attack on Chinese workers developing natural gas operations in the Ogaden threatened Ethiopia's relationships with important international investors. Ethiopian armed forces responded with a ferocious counter-insurgency campaign

\footnotetext{
${ }^{9}$ For context see, Abdi M. Abdullahi, "The Ogaden National Liberation Front (ONLF): The Dilemma of Its Struggle in Ethiopia," Review of African Political Economy 34, no. 113 (September 2007), 556-562.

${ }^{10}$ Terrence Lyons and Peter Mandaville, eds., Politics from Afar: Transnational Diasporas and Networks (Oxford: Oxford University Press, 2011).
} 
that generated massive displacement and allegations of widespread human rights violations. ${ }^{11}$ Addis Ababa perceived the ONLF as part of a regional network of threats that linked the Ogadeni movement to Eritrea, the Islamic Courts in Somalia, and the Oromo Liberation Front.

The conflict in the Ogaden region led the regime in Addis Ababa as well as the ONLF to mobilize different groups to mobilize transnationally. These competing transnational campaigns sought to shape the policies of governments and international organizations, and the ONLF further sought to influence prominent international advocacy groups and human rights organizations. Diaspora supporters sought to frame the conflict in the Ogaden in terms of human rights and international law:

We are also extremely concerned with the ongoing and widespread violations of human rights in the Ogaden, specifically the right to life, the right not to be subjected to torture or to cruel, inhuman or degrading treatment or punishment, the right to liberty and security, the right to a fair trial and the rights to freedom of assembly, association and expression. ${ }^{12}$

The ONLF and its supports emphasized that violence in eastern Ethiopia should be understood as "war crimes" and urged the UN to "halt the unfolding of yet another preventable African genocide." ${ }^{13}$ The Ethiopian government, in turn, claimed that the ONLF was a terrorist organization and therefore a legitimate target for security forces. The ONLF response alleged that the ruling party was guilty of "war crimes" and that the "real terrorists are the Ethiopian government."14 The ONLF and its supporters intentionally borrowed the framing used by activists who sought to mobilize the international community around the violence in Darfur. Both the ONLF activists and the Ethiopian government recognized the importance of framing the issue to actors outside of Ethiopia and that external understandings might shape the outcome of the conflict.

These dynamics were illustrated by a particular episode in August 2009 when a governmentled delegation from the Somali National Regional State visited diaspora leaders in Sweden and North America to brief them on current developments and to encourage investment. The ruling authorities sought to characterize the ONLF as an "instrument of other anti-peace elements in Somalia and Eritrea who have been playing a game with the blood of the innocent civilians in Somalia for the last eighteen years and who want to import the same game into the people of the Somali region of Ethiopia."15 The Ogadeni diaspora leaders mobilized to counteract this narrative and to challenge the tour. The diaspora recognized the delegation's visit as an opportunity to educate and influence the international community and leaders. The diaspora issued a press release noting their "shock" that visas would be issued to these "perpetrators of crimes against humanity in the Ogaden Region."16 An editorial on the diaspora-run Ogaden.com website named specific individuals within the visiting delegation and insisted that all were "directly responsible

\footnotetext{
11 "Collective Punishment: War Crimes and Crimes against Humanity in the Ogaden Area of Ethiopia's Somali Region," Human Rights Watch, June 12, 2008, accessed June 1, 2018, https:/www.hrw.org/report/2008/06/12/collectivepunishment/war-crimes-and-crimes-against-humanity-ogaden-area-ethiopias.

12 "The Arrival of Perpetrators of Crimes Against Humanity in the Ogaden," (press release, August 16, 2009, accessed June 1, 2018, http://rasaasa.com/your-excellencies/.

${ }^{13}$ Wangui Kanina, “Ethiopia's Ogaden Rebels Warn of 'African Genocide'," Reuters, September 13, 2007, accessed March 31, 2019, https://www.reuters.com/article/us-ethiopia-rebels/ethiopias-ogaden-rebels-warn-of-african-genocideidUSL1385784520070913.

${ }^{14}$ Brian Kennedy, "Ethiopia: Ogaden Leaders Accuse Government of 'Genocide'," allAfrica, September 13, 2007, accessed June 1, 2018, https://allafrica.com/stories/200709130518.html. Quote from ONLF Chairman Mohamed Osman.

${ }^{15}$ See, "Somali-Ethiopian Officials Visit Ogaden Diaspora in Sweden" (press release, Ethiopian Embassy, Stockholm, 18 August 2009), accessed June 1, 2018, https://www.hiiraan.com/news2/2009/aug/somali ethiopian officials visit ogaden diaspora in sweden.aspx. For a press release that emphasizes diaspora protests in Stockholm see, "Accomplices of the Ethiopian Army War Criminals Visits Sweden and Met the Wrath of the Ogaden Community in both countries," (Statement by the Ogaden Somalia Communities Abroad, Sweden, August 25, 2009), accessed June 1, 2018, http://www.dehai.org/archives/dehai news archive/jul-sept09/0540.html.

${ }^{16}$ The Arrival of Perpetrators.
} 
for the genocide that has, and continues to date, taken place in Ogaden."17 The statement went on to urge those whose relatives are victims of the "Ogaden genocide" to lodge criminal complaints in Sweden and elsewhere against members of the delegation. "We beg these victims to use the European, American, or African legal systems to bring these perpetrators to justice." 18

Recognizing that that the legal and political systems in northern Europe and the US offered opportunities for certain strategies that were not available in the homeland, the ONLF and its sympathizers deployed the diaspora to protest, demonstrate and generally increase the profile of the liberation movement. An October 2008 demonstration in front of the State Department delivered a letter protesting "widespread human rights violations"19 and a November 2008 protest in Parliament Square in London was advertised as a "protest against genocide and crimes against humanity in Ogaden." ${ }^{20}$ Working with transnational advocacy networks, protestors targeted Prime Minister Meles Zenawi whenever he visited Europe or North America. Diasporic Ogadeni advocates took advantage of the opportunity of Meles' participation in the global summit on climate change in Copenhagen in December 2009 to accuse him of committing genocide in Ogaden ${ }^{21}$ and then again protested Meles when he gave a talk in September 2010 at Columbia University in New York..$^{22}$

The Ethiopian government explicitly named the ONLF, along with the Oromo Liberation Front and Ginbot 7, as terrorists groups alongside international groups like Al-Qaeda and AlShabaab. Deputy Prime Minister (and later Prime Minister) Hailemariam Dessalegn noted that the international community asked for cooperation from the developing states to support the global war on terror but refused to recognize groups active in places like Ethiopia as terrorist. He complained of a "double standard" in the fight against terrorism and pressured Washington to place these opposition groups on its terrorist list. ${ }^{23}$ "Terrorists who targeted Africans were not treated as seriously as terrorists who targeted Americans." ${ }^{24}$ A pro-EPRDF website even asked why

17 "Bring Ogaden Genocide Perpetrators to Justice," Ogaden online editorial, August 16, 2009, accessed June 1, 2018 ,https:// web.archive.org/web/20090819151209/http://ogaden.com/editorial/409-bring-ogaden-genocide-perpetrators-tojustice. The editorial stated: "There is no doubt that the extrajudicial killings, rape, and gruesome maiming reported in Ogaden perfectly fit the legal definition of genocide. There is also a consensus of opinion as to who the Ogaden genocide perpetrators are. These genocidal criminals include those who plan, direct, and carryout genocidal crimes against the Ogaden citizenry. Individuals such as Da'ud (Amhar), the head of the so-called Somali administration, Abdi Iley, the head of the Security Bureau, the heads of the Woyane militias and their marauding militias including the local militias, and the head of the current Tigrian clique in Addis Ababa Mr. Meles Zenawi are now part of what is locally dubbed as the Ogaden genocide marshals (OGM)."

${ }^{18}$ Bring Ogaden Genocide Perpetrators to Justice. The editorial stated: "There is no doubt that the extrajudicial killings, rape, and gruesome maiming reported in Ogaden perfectly fit the legal definition of genocide. There is also a consensus of opinion as to who the Ogaden genocide perpetrators are. These genocidal criminals include those who plan, direct, and carry out genocidal crimes against the Ogaden citizenry. Individuals such as Da'ud (Amhar), the head of the so-called Somali administration, Abdi Iley, the head of the Security Bureau, the heads of the Woyane militias and their marauding militias, and the head of the current Tigrian clique in Addis Ababa Mr. Meles Zenawi are now part of what is locally dubbed as the Ogaden Genocide Marshals."

19 "Ethiopians Protest at the US State Department against Human Rights Violations in the Ogaden," (press release, October 26, 2008), accessed June 1, 2018, http://abbaymedia.com/News/?p=1890.

20 "UK-Mass Demonstration Planned in Front of UK House of Parliament" (press release, October 29, 2008), accessed June 1, 2018, http://mareeg.com/fidsan.php?sid=8587\&tirsan=9.

${ }^{21}$ See, "Members of the Europian [sic] Ogaden Community Demonstrate Againist [sic] Meles Zenawi," Ogaden.com, December 18, 2009, accessed June 1, 2018, https://web.archive.org/web/20091231030556/http://www.ogaden.com/ hornnews/ethiopia/563-members-of-the-europian-ogaden-community-demonestrate-againist-meles-zenawi

${ }^{22}$ See, Resolve Ogaden Coalition, “Ogaden-Ethiopia: Open Letter from Resolve Ogaden Coalition to Columbia University," (statement, New York, September 17, 2010), accessed June 1, 2018, http://gadaa.com/ oduu/5670/2010/09/17/ogaden-ethiopia-open-letter-from-resolve-ogaden-coalition-to-columbia-university/.

${ }^{23}$ H. E. Mr. Hailemariam Desalegn, statement at the General Debate of the $66^{\text {th }}$ Session of the United Nations General Assembly (statement, New York, September 26, 2011), accessed June 1, 2018, http://aigaforum.com/news/DPMstatment-to-UNGA-66.pdf

24 "Terrorism, Double Standards, and the International Community," Ethiopian Ministry of Foreign Affairs, November 21, 2008, accessed June 1, 2018, http://www.aigaforum.com/articles/MFA international double standarad terrorism 112108.htm. 
"Ethiopia's most wanted terrorist roam America freely!" 25 Classifying ONLF, OLF, or Ginbot 7 as terrorist groups would make the important fund raising that each of these groups did in the United States illegal. Washington, however, did not place these groups on the list and therefore political activities and most importantly fundraising in the United States continued. ${ }^{26}$

Other opposition groups active in the diaspora followed the ONLF's example and sought to demonstrate to Western policy makers and advocacy networks that the Ethiopian regime was engaging in genocide. Opposition to the EPRDF's policies was expressed in terms of genocide in part to mobilize the broader international community. The Human Rights League of the Horn of Africa, for example, noted that the regime in Addis Ababa engaged in "genocide and ethnic cleansing" in the name of development. The statement went on to express deep concern that if the international community fails "in responding to the merciless killings presently taking place in Oromia Regional State as soon as possible, this could lead to a genocide comparable to those in Rwanda (1994), in Yugoslavia (1998) and in Darfur, Sudan (2003)." ${ }^{27}$ US-based scholars published articles on "clandestine genocide" and "genocide denial" in Ethiopia. ${ }^{28}$

The Amhara diaspora in particular followed the Ogadeni diaspora in its use of the genocide frame. The Moresh Wegenie Amara Organization issued a report that characterized political violence in the Benishangul-Gumuz as "Genocide Committed against the Amhara." ${ }^{29}$ A documentary film on the "Genocide of Amharas" was posted on YouTube in 2016. ${ }^{30}$ These reports circulated widely on diaspora media sites, radio stations, and served as the basis for petition drives on change.org. ${ }^{31}$ The transnational advocacy efforts by many political actors in the diaspora saw powerful leverage in the genocide framing. Activists used comparisons to Rwanda in their efforts to influence how the international community understood violence in Ethiopia ${ }^{32}$ and used Facebook to mobilize against Secretary of State Hilary Clinton and President Barack Obama for their silence on the issue. ${ }^{33}$ Activists built upon the power of the genocide label in their strategies to lobby policy makers.

Ethiopian transnational advocacy did help shape perceptions in the United States and elsewhere. The global advocacy organization Genocide Watch issued a Genocide Alert and considered conditions in Ethiopia "have already reached Stage 7, genocidal massacres, against many of its peoples, including the Anuak, Ogadeni, Oromo, and Omo tribes." ${ }^{34}$ In 2017, Tewodrose G. Tirfe, a Board Member of the Amhara Association of America, testified before the US House of

${ }^{25}$ Dag Dange, "Would the US Immigration Grant Asylum for Al Qaeda or Ginbot 7?" April, 28, 2009, accessed, June 1, 2018, http://www.aigaforum.com/articles/Dag_on_Ginbot7.htm.

${ }^{26}$ Brian Kennedy, "Ethiopia: Advocate Says Ogaden Crisis Strikingly Similar to Darfur," allAfrica, October 3, 2007, accessed June 1, 2018, https://allafrica.com/stories/200710031116.html.

${ }^{27}$ The Human Rights League of the Horn of Africa, "Ethiopia: The TPLF Hidden Agenda of Reducing the Oromo Population Must be Stopped," (press release, Washington, DC, April 17, 2016), accessed June 1, 2018, http:// oromoliberationfront.org/en/ethiopia-the-tplf-hidden-agenda-of-reducing-the-oromo-population-must-be-stopped/.

${ }^{28}$ Asafa Jalata and Harwood Schaffer, "The Ethiopian State: Authoritarianism, Violence, and Clandestine Genocide," Journal of Pan African Studies 3, no. 6 (March 2010), 160-189. Asafa sees $19^{\text {th }}$ century Abyssinian imperialism as genocidal with regard to the Oromo; Habtamu Dugo and Joanne Eisen, "The Politics of Genocide Denial in Ethiopia," Africology: The Journal of Pan African Studies 11, no. 4 (March 2018), 61-89.

${ }^{29}$ Moresh Wegenie Amara Organization, Genocide Committed against the Amara (Amhara) in Ethiopia, specifically the Benishangul-Gumuz Regional State, Metekel Zone, Special Report on Genocide against the Amara (Amhara), August 18, 2015, accessed June 1, 2018, http://genocidewatch.net/wp-content/uploads/2016/01/MWAO Genocide-Report V3No1 Tue0Aug2015 Genocide-Committed-Against-the-Amara-Amhara-in-Benshangul-Gumuz-Regional-StateMetekel-Zone-1.pdf.

30"The Genocide and Deportation of the Amharas," Youtube video, August 16, 2016, accessed June 1, 2018, https://www. youtube.com/watch?v=lnP-o7vpVko.

31 "Stop State-sponsored Genocide of Amhara People in Ethiopia," petition, accessed June 1, 2018, https://www.change. org/p/stop-state-sponsored-genocide-of-amhara-people-in-ethiopia. (video content no longer available)

${ }^{32}$ Teshome M. Borago, “Is Ethiopia a Rwandan Genocide in the Making?" Madote, March 2018, accessed June 1, 2018, http://www.madote.com/2017/10/ethiopia-is-slowly-sleepwalking-into.html.

${ }^{33}$ Haileyesus-Adamu Broadcasting Network, "Protest Hilary Clinton and Stop the Amhara people Genocide," Facebook event, Washington, DC, September 17, 2016, accessed June 1, 2018, https://www.facebook.com/ events/198667490538792/.

${ }^{34}$ See, Genocide Watch, “Genocide Alert: Ethiopia,” December 6, 2012, accessed June 1, 2018, http://genocidewatch. net/2012/12/06/genocide-watch-emergency-ethiopia/. 
Representatives Subcommittee on Africa, Global Health, Global Human Rights, and International Organizations on the "horrendous act of genocide and ethnic cleansing" being committed by the Ethiopian government against the Amhara. ${ }^{35}$ Not all opponents to the Ethiopian regime favored the genocide frame but the label is so powerful that it played a major part in how key organizations understood Ethiopia.

\section{Conclusion}

Neither the Ethiopian government's goal of having the ONLF and other opposition groups classified as terrorist groups nor the goal of the ONLF's supporters to have the regime labeled as engaging in genocide succeeded. However, the advocacy campaigns each had some role in preventing the other side's campaign from successfully shifting international policy toward the conflict in the Ogaden. Challenging the adoption of a label that disadvantages your policy agenda is an important goal. Furthermore, what we see through this case study is that questions around what is genocide are recognized by all parties to a conflict as a key arena of the larger contention. The ONLF would have suffered a severe setback if Addis Ababa had succeeded in having them placed on the list of terrorist organizations. The Ethiopian government would have experienced significant hurdles in its efforts to retain strong relations with global partners if the international community had determined that it was engaging in genocide. The outcome of this kind of contentious transnational advocacy work is shaped in significant measure by diaspora networks and their ability to engage in lobbying from their positions outside of Ethiopia.

\section{Bibliography}

"Accomplices of the Ethiopian Army War Criminals Visits Sweden and Met the Wrath of the Ogaden Community in both countries." Statement by the Ogaden Somalia Communities Abroad, Sweden, August 25, 2009. Accessed June 1, 2018. http://www.dehai.org/archives/ dehai_news_archive/jul-sept09/0540.html.

Abdullahi, Abdi M. "The Ogaden National Liberation Front (ONLF): The Dilemma of Its Struggle in Ethiopia." Review of African Political Economy 34, no. 113 (September 2007), 556-562.

Bellamy, Alex. "The Islamic State and the Case for Responsibility to Protect." OpenCanada.org, April 20, 2015. Accessed June 1, 2018. https://www.opencanada.org/features/the-islamicstate-and-the-case-for-responsibility-to-protect/.

Bob, Clifford. The Marketing of Rebellion: Insurgents, Media, and International Activism. New York: Cambridge University Press, 2005. DOI: 10.1007/s11558-006-9494-4

. The Global Right Wing and the Clash of World Politics. New York: Cambridge University Press, 2012.

Borago, Teshome M. “Is Ethiopia a Rwandan Genocide in the Making?” Madote, March 2018. Accessed June 1, 2018. http://www.madote.com/2017/10/ethiopia-is-slowly-sleepwalkinginto.html.

"Bring Ogaden Genocide Perpetrators to Justice." Ogaden online editorial, August 16, 2009. Accessed June 1, 2018. https://web.archive.org/web/20090819151209/http://ogaden.com/ editorial/409-bring-ogaden-genocide-perpetrators-to-justice.

Carpenter, R. Charli. "Setting the Advocacy Agenda: Theorizing Issue Emergence and Nonemergence in Transnational Advocacy Networks." International Studies Quarterly 51, no.1 (2007), 99-120. DOI: 10.1111/j.1468-2478.2007.00441.x

"Collective Punishment: War Crimes and Crimes against Humanity in the Ogaden Area of Ethiopia's Somali Region." Human Rights Watch. June 12, 2008. Accessed June 1, 2018. https://www.hrw.org/report/2008/06/12/collective-punishment/war-crimes-and-crimesagainst-humanity-ogaden-area-ethiopias.

\footnotetext{
${ }^{35}$ Tewodrose G. Tirfe, Board Member, Amhara Association of America, (hearing statement, Democracy Under Threat in Ethiopia hearing, Washington, DC, March 9, 2017), U.S House of Representatives Committee on Foreign Affairs, Africa, Global Health, Global Human Rights, and International Organizations Subcommittee, accessed, June 1, 2018, http://docs.house.gov/meetings/FA/FA16/20170309/105673/HHRG-115-FA16-Wstate-TirfeT-20170309.pdf.
} 
Dange, Dag. “Would the US Immigration Grant Asylum for Al Qaeda or Ginbot 7?” April, 28, 2009. Accessed, June 1, 2018. http://www.aigaforum.com/articles/Dag on Ginbot7.htm.

Desalegn, H. E. Mr. Hailemariam. Statement at the General Debate of the $66^{\text {th }}$ Session of the United Nations General Assembly. Statement, New York, September 26, 2011. Accessed June 1, 2018. http://aigaforum.com/news/DPM-statment-to-UNGA-66.pdf.

Dugo, Habtamu and Joanne Eisen. "The Politics of Genocide Denial in Ethiopia." Africology: The Journal of Pan African Studies 11, no. 4 (March 2018), 61-89.

"Ethiopians Protest at the US State Department against Human Rights Violations in the Ogaden." Press release, October 26, 2008. Accessed June 1, 2018. http://abbaymedia.com/ News/?p=1890.

Genocide Watch. "Genocide Alert: Ethiopia." December 6, 2012. Accessed June 1, 2018. http:// genocidewatch.net/2012/12/06/genocide-watch-emergency-ethiopia/.

Haileyesus-Adamu Broadcasting Network. "Protest Hilary Clinton and Stop the Amhara people Genocide." Facebook event. Washington DC, September 17, 2016. Accessed June 1, 2018. https://www.facebook.com/events/198667490538792/.

Heine, Jorge and Ramesh Thakur, eds. The Dark Side of Globalization. New York: United Nations University Press, 2011.

Human Rights League of the Horn of Africa. "Ethiopia: The TPLF Hidden Agenda of Reducing the Oromo Population Must be Stopped." Press release, Washington, DC, April 17, 2016. Accessed June 1, 2018. http://oromoliberationfront.org/en/ethiopia-the-tplf-hiddenagenda-of-reducing-the-oromo-population-must-be-stopped/.

Irvin-Erickson, Douglas. "Genocide Discourses: American and Russian Strategic Narratives of Conflict in Iraq and Ukraine." Politics and Governance 5, no. 3 (2017), 130-145. DOI: 10.17645/pag.v5i3.1015

Jalata, Asafa and Harwood Schaffer. "The Ethiopian State: Authoritarianism, Violence, and Clandestine Genocide." Africology: The Journal of Pan African Studies 3, no. 6 (March 2010), 160-189.

Kanina, Wangui. "Ethiopia's Ogaden Rebels Warn of "African Genocide"." Reuters, September 13, 2007. Accessed March 31, 2019. https://www.reuters.com/article/us-ethiopia-rebels/ ethiopias-ogaden-rebels-warn-of-african-genocide-idUSL1385784520070913.

Keck, Margaret E., and Kathryn Sikkink. Activists Beyond Borders: Advocacy Networks in International Politics. Ithaca: Cornell University Press, 1998. DOI: 10.7591/9780801471292

Kennedy, Brian. "Ethiopia: Advocate Says Ogaden Crisis Strikingly Similar to Darfur." allAfrica, September 13, 2007. Accessed June 1, 2018. https://allafrica.com/stories/200710031116.html.

---------. "Ethiopia: Ogaden Leaders Accuse Government of 'Genocide'." allAfrica, September 13, 2007. Accessed June 1, 2018. https://allafrica.com/stories/200709130518.html. Quote from ONLF Chairman Mohamed Osman.

Lyons, Terrence, and Peter Mandaville, eds. Politics from Afar: Transnational Diasporas and Networks. Oxford: Oxford University Press, 2011.

Mamdani, Mahmood. "The Politics of Naming: Genocide, Civil War, Insurgency." London Review of Books 29, no. 5 (March 8, 2007), 5-8.

"Members of the Europian [sic] Ogaden Community Demonstrate Againist [sic] Meles Zenawi." Ogaden.com, December 18, 2009. Accessed June 1, 2018. https://web.archive.org/ web/20091231030556/http://www.ogaden.com/hornnews/ethiopia/563-members-of-theeuropian-ogaden-community-demonestrate-againist-meles-zenawi.

Moresh Wegenie Amara Organization. Genocide Committed against the Amara (Amhara) in Ethiopia, specifically the Benishangul-Gumuz Regional State, Metekel Zone. Special Report on Genocide against the Amara (Amhara). August 18, 2015. Accessed June 1, 2018. http://genocidewatch. net/wp-content/uploads/2016/01/MWAO Genocide-Report V3-No1 Tue0Aug2015 Genocide-Committed-Against-the-Amara-Amhara-in-Benshangul-Gumuz-RegionalState-Metekel-Zone-1.pdf.

Resolve Ogaden Coalition. "Ogaden-Ethiopia: Open Letter from Resolve Ogaden Coalition to Columbia University. Statement, New York, September 17, 2010. Accessed June 1, 2018. 
http://gadaa.com/oduu/5670/2010/09/17/ogaden-ethiopia-open-letter-from-resolveogaden-coalition-to-columbia-university/.

"Somali-Ethiopian Officials Visit Ogaden Diaspora in Sweden." Press release. Ethiopian Embassy, Stockholm, August 18, 2009. Accessed June 1, 2018. https://www.hiiraan.com/news2/2009/ aug/somali ethiopian officials visit ogaden diaspora in sweden.aspx.

"Stop State-sponsored Genocide of Amhara People in Ethiopia." Petition. Accessed June 1, 2018. https://www.change.org/p/stop-state-sponsored-genocide-of-amhara-people-in-ethiopia. (video content no longer available)

"Terrorism, Double Standards, and the International Community." Ethiopian Ministry of Foreign Affairs, November 21, 2008. Accessed June 1, 2018. http://www.aigaforum.com/articles/ MFA international double standarad terrorism 112108.htm.

"The Arrival of Perpetrators of Crimes Against Humanity in the Ogaden." Press release, August 16, 2009. Accessed June 1, 2018. http://rasaasa.com/your-excellencies/.

"The Genocide and Deportation of the Amharas." YouTube Video, August 16, 2016. Accessed June 1, 2018, https://www.youtube.com/watch?v=lnP-o7vpVko.

Tirfe, Tewodrose G., Board Member, Amhara Association of America. Hearing statement, Democracy Under Threat in Ethiopia hearing. Washington, DC, March 9, 2017. U.S. House of Representatives Committee on Foreign Affairs, Africa, Global Health, Global Human Rights, and International Organizations Subcommittee. Accessed, June 1, 2018. http://docs. house.gov/meetings/FA/FA16/20170309/105673/HHRG-115-FA16-Wstate-TirfeT-20170309. pdf.

“UK-Mass Demonstration Planned in Front of UK House of Parliament." Press release, October 29, 2008. Accessed June 1, 2018. http://mareeg.com/fidsan.php?sid=8587\&tirsan=9. 